\title{
Determination of ptaquiloside in cow's milk by HPLC-UV
}

\section{Determinação de ptaquilosídeo no leite de vacas por CLAE-UV}

\author{
Debora da Silva Freitas Ribeiro'; Kelly Moura Keller²; Marília Martins Melo²; \\ Benito Soto-Blanco ${ }^{2 *}$
}

\begin{abstract}
Ferns of the genus Pteridium are known to be responsible for cases of poisoning in cattle. The commonly found species of Pteridium in Brazil are P. arachnoideum and P. caudatum. The toxic principle of these ferns is ptaquiloside, a norsesquiterpene glucoside, which is a known carcinogen. Ptaquiloside can be secreted in the milk of cows grazing on bracken ferns, thereby posing a potential health risk for the milk consumers. The objective of the present study was to develop an analytical methodology using high performance liquid chromatography (HPLC) with ultraviolet (UV) detection to determine the concentrations of ptaquiloside in cow's milk. HPLC-UV method, based on the conversion of ptaquiloside into pterosin B and its subsequent extraction using dichloromethane, was successfully developed for estimating concentrations of ptaquiloside in milk samples. However, the presence of ptaquiloside was not detected in milk samples obtained from cows with a history of bovine enzootic hematuria resulting from grazing on P. arachnoideum infested pastures in Brazil.
\end{abstract}

Key words: Pteridium aquilinum. Pteridium arachnoideum. Ptaquiloside. Milk. Poisonous plants.

\section{Resumo}

Samambaias do gênero Pteridium são reconhecidas como responsáveis por casos de intoxicação em bovinos. As espécies de Pteridium comumente encontradas no Brasil são $P$. arachnoideum e $P$. caudatum. O princípio tóxico dessas plantas é o ptaquilosídeo, um glicosídeos norsesquiterpênico, que é um conhecido carcinógeno. O ptaquilosídeo pode ser excretado no leite de vacas que consomem a samambaia, o que representa um potencial risco para quem o consuma. O objetivo do presente trabalho foi desenvolver uma metodologia analítica utilizando cromatografia líquida de alta eficiência (CLAE) com detecção por ultravioleta (UV) para a determinação das concentrações do ptaquilosídeo no leite bovino. Foi desenvolvida com sucesso uma metodologia analítica utilizando CLAE-UV para a determinação das concentrações do ptaquilosídeo no leite, baseada na conversão deste composto em pterosina B e posterior extração utilizando diclorometano. Entretanto, não foi detectada a presença de ptaquilosídeo nas amostras de leite de propriedades com histórico de hematúria enzoótica bovina e que possuíam $P$. arachnoideum na pastagem.

Palavras-chave: Pteridium aquilinum. Pteridium arachnoideum. Ptaquilosídeo. Leite. Plantas tóxicas.

${ }^{1}$ Prof $^{\mathrm{a}} \mathrm{Dr}^{\mathrm{a}}$, Centro Universitário de Mineiros, UNIFIMES, Mineiros, GO, Brasil. E-mail: deboradasfr@unifimes.edu.br

2 Profs. Drs., Departamento de Clínica e Cirurgia Veterinárias, Escola de Veterinária, Universidade Federal de Minas Gerais, UFMG, Belo Horizonte, MG, Brasil. E-mail: kelly.medvet@gmail.com; mariliamm@ufmg.br; benito.blanco@pq.cnpq.br

* Author for correspondence 
Pteridium aquilinum was previously classified as the sole species in the genus Pteridium with global distribution; however, recently up to 11 different species have been identified under this genus. Two species of genus Pteridium that are found in Brazil are Pteridium arachnoideum and Pteridium caudatum (YANEZ et al., 2016). These two species of bracken ferns are found mainly, but not exclusively, in the South and Southeast regions of Brazil, and are known to be responsible for important economic losses in the national cattle population owing to their toxic effects on them (ANJOS et al., 2008; FURLAN et al., 2014).

Toxic effects resulting from consumption of bracken ferns vary depending on the animal species, the ingested dose, and the length of consumption of these ferns. Clinical conditions arising in animals due to its consumption include cyanide poisoning, thiamine deficiency in monogastric animals, progressive retinal degeneration in sheep, acute hemorrhagic syndrome or hemorrhagic diathesis, bovine enzootic hematuria, and upper gastrointestinal tract neoplasia; of these, only the latter three conditions have been reported in Brazilian cattle (ANJOS et al., 2008; FURLAN et al., 2014). However, it is also important to mention that ferns of species other than Pteridium can also cause poisoning of livestock (MICHELOUD et al., 2017).

Plants of Pteridium aquilinum complex contain several active principles, the most toxicological being ptaquiloside, a norsesquiterpene glucoside, which under alkaline $\mathrm{pH}$ conditions gets converted into dienone, a potent DNA alkylating agent with carcinogenic activity (YAMADA et al., 2007). This compound can be secreted in milk (ALONSOAMELOT et al., 1998; FRANCESCO et al., 2011) presenting a potential health risk to the consumers of contaminated milk. However, the frequency and the amount of ptaquiloside contamination in milk obtained from Brazilian cattle, has not yet been well elucidated. The lack of data is due to complexity of the analytical methods used for determining concentrations of ptaquiloside, and therefore, it is necessary to develop a quick and easy methodology that can be applied to a large number of national laboratories.

Thus, the objective of the present study was to develop an analytical methodology using high performance liquid chromatography (HPLC) with ultraviolet (UV) detection for determining the concentrations of ptaquiloside in dairy milk.

Milk samples used for the development and evaluation of the analytical technique in this study were obtained from cows having no contact with bracken ferns from the Ruminants Sector of the Veterinary Hospital, Veterinary School, Universidade Federal de Minas Gerais (UFMG), Belo Horizonte-MG, Brazil. For the validation of the analytical technique, 20 milk samples were used from small farms in the region of Ouro Branco/MG, Brazil, which was infested with $P$. arachnoideum and had cattle with known cases of bovine enzootic hematuria.

The analytical methodology was based on the conversion of ptaquiloside to pterosin $\mathrm{B}$ under alkaline $\mathrm{pH}$ conditions. Three extraction and cleanup methods have been compared below:

Extraction method A (Quick, Easy, Cheap, Effective, Rugged and Safe (QuEChERS) method adapted from Oliveira et al. (2014): In a $50 \mathrm{~mL}$ Falcon tube, $10 \mathrm{~mL}$ of milk was mixed with $10 \mathrm{~mL}$ of acidified (with $0.1 \%$ acetic acid) acetonitrile and vortexed for $1 \mathrm{~min}$ followed by addition of $1 \mathrm{~g}$ of anhydrous sodium acetate and $4 \mathrm{~g}$ of magnesium sulfate. The tube was vortexed for $1 \mathrm{~min}$, centrifuged at $4000 \mathrm{rpm}$ for $11 \mathrm{mins}$, and then frozen at $-20^{\circ} \mathrm{C}$ for $24 \mathrm{~h}$. A total of $5 \mathrm{ml}$ of the supernatant was pipetted into another Falcon tube containing 750 $\mathrm{mg}$ of magnesium sulfate, followed by vortexing for $1 \mathrm{~min}$, and finally centrifuged at $4000 \mathrm{rpm}$ for 9 mins. The supernatant $(1.0 \mathrm{~mL})$ was pipetted into a vial and stored at $-20{ }^{\circ} \mathrm{C}$ until the time of injection into HPLC-UV system. 
Extraction method B: In a $50 \mathrm{ml}$ Falcon tube, $10 \mathrm{ml}$ of milk and $10 \mathrm{ml}$ of methanol were mixed and vortexed for $1 \mathrm{~min}$, followed by addition of $1 \mathrm{~g}$ of anhydrous sodium acetate and $4 \mathrm{~g}$ of magnesium sulfate. This mixture was vortexed for $1 \mathrm{~min}$, centrifuged at $4000 \mathrm{rpm}$ for $11 \mathrm{mins}$, and frozen at $-20{ }^{\circ} \mathrm{C}$ for $24 \mathrm{~h}$. A total of $5 \mathrm{ml}$ of the supernatant was transferred into another Falcon tube containing $750 \mathrm{mg}$ of magnesium sulfate, vortexed for $1 \mathrm{~min}$, and centrifuged at $4000 \mathrm{rpm}$ for 9 mins. The extract $(1.0 \mathrm{~mL})$ was pipetted into a vial and stored at -20 ${ }^{\circ} \mathrm{C}$ until the time of injection into HPLC-UV system.

Extraction method C: In a $50 \mathrm{~mL}$ Falcon tube, 10 mL of milk and $10 \mathrm{~mL}$ of $0.04 \mathrm{M}$ potassium hydroxide solution $(\mathrm{KOH})$ were added and homogenized. Each tube was incubated in water bath at $40{ }^{\circ} \mathrm{C}$ for $2 \mathrm{~h}$. After incubation, $10 \mathrm{~mL}$ of dichloromethane was added, homogenized and frozen at $-20{ }^{\circ} \mathrm{C}$ for $24 \mathrm{~h}$. The samples were then thawed and centrifuged. The extractions with dichloromethane were repeated twice, and the extracts were filtered through 500 $\mathrm{g}$ of silica gel (Merck, Darmstadt, Germany) and dried at room temperature in a fume hood. The extract was stored at $-20^{\circ} \mathrm{C}$ and was resuspended in $500 \mu \mathrm{L}$ methanol just before injection into HPLCUV system.

Pterosin B was isolated from P. arachnoideum sprouts, as described by Ribeiro (2018), and used as an analytical standard. The chemical identity of pterosin B was confirmed using mass spectrometer (Waters Acquity UPLC system coupled to Xevo ${ }^{\mathrm{TM}}$ G2-S QTof), and the purity was determined by HPLC-UV system (Severn Analytical SA6410B ${ }^{\circledR}$ with UV/Vis SA6510 detector). The analytical standard was resuspended in methanol to make stock solution of $20 \mathrm{mmol} / \mathrm{L}$ concentration and stored at $-20{ }^{\circ} \mathrm{C}$. The working solutions of $5.0,2.5,1.25$, $0.625,0.3125$, and $0.15625 \mathrm{mmol} / \mathrm{L}$ concentrations were prepared by diluting the stock solution with methanol.

After extraction, the concentration of pterosin B in the sample was detected using a HPLC-UV system
(LC-2000Plus, JASCO, Tokyo, Japan), as described by Agnew and Lauren (1991). For separation, an Octadecylsilyl (ODS) column (Shim-pack CLCODS (M), $4.6 \times 150 \mathrm{~mm}$, particle diameter of $5 \mu \mathrm{m}$ ) was used with acetonitrile:methanol:acidified (with $1 \mathrm{mM}$ acetic acid) water (25: 25:50) as the mobile phase. Aliquots of $20 \mu \mathrm{l}$ were injected into HPLCUV system and were isocratically evaluated at a flow rate of $1.2 \mathrm{~mL} / \mathrm{min}$. The eluted fractions were then detected at a wavelength of $230 \mathrm{~nm}$. For calibration, pterosin B was used as an analytical standard at concentrations described previously and calibration curve was constructed. The chromatographic data were collected and processed using the ChromNAV v.1.16 software.

For determining the selectivity, occurrence of any interfering compound eluting at the retention time of the analyte of interest was verified by comparing the chromatograms generated from the analysis of blank samples with the chromatograms obtained from the analysis of blank samples spiked with pterostin B.

For determining the linearity, calibration curves for different concentrations of the analyte were constructed in triplicates. The peak area values were plotted against the concentration of analyte and the calibration curves were constructed using linear regression by Ordinary Least Squares method. A standard graph of peak area value versus different concentrations of the analyte was constructed and the analytical curve equation, the coefficient of determination $\left(\mathrm{R}^{2}\right)$, and correlation coefficient $(\mathrm{r})$ were determined using linear regression analysis.

The limit of detection (LOD) was determined by the visual method after analyzing the results from different known concentrations of the analyte and the signal could be distinguished from the noise at the lowest concentration of analyte used with a signal-to-noise ratio of 3:1. Signal-to-noise ratio of 10:1 was used for determination of the limit of quantification (LOQ) (INMETRO, 2011). This analysis was performed by evaluating six replicates for each sample. 
Accuracy of the method was assessed by performing recovery assays on the samples. For this, blank samples were fortified with low $(0.125$ $\mathrm{mmol} / \mathrm{L})$, medium $(0.5 \mathrm{mmol} / \mathrm{L})$ and high (1.0 $\mathrm{mmol} / \mathrm{L}$ ) concentrations of pterosin $\mathrm{B}$ and detected on HPLC-UV system. The recovery was calculated by dividing the concentration of pterosin $\mathrm{B}$ obtained from the analytical technique by its theoretical concentration and multiplied with 100 to obtain the percentage of pterosin $\mathrm{B}$ recovered.

In the present study, three methods for extraction and clean-up of ptaquiloside from milk samples were compared. Extraction method A (QuEChERS method) and B were not found to be accurate as assessed by recovery assays. Both these extraction methods were inefficient in recovering pterosin B from milk samples with $1.0 \mathrm{mmol} / \mathrm{L}$ concentration of pterosin B. On the other hand, extraction method $\mathrm{C}$ was found to be efficient, and therefore, further validation was carried out for this method.

Chromatograms of pterosin B and blank matrix (milk) showed good sensitivity for detecting the analyte (Figure 1). The evaluation of linearity was conducted by plotting the analytical curves. F-test showed homoscedasticity, and therefore, the Ordinary Least Squares Method (MMQO) was applied to fit the analytical curves in the validation test.

Figure 1. Chromatograms of the milk sample added with pterosin B, an analytical standard.

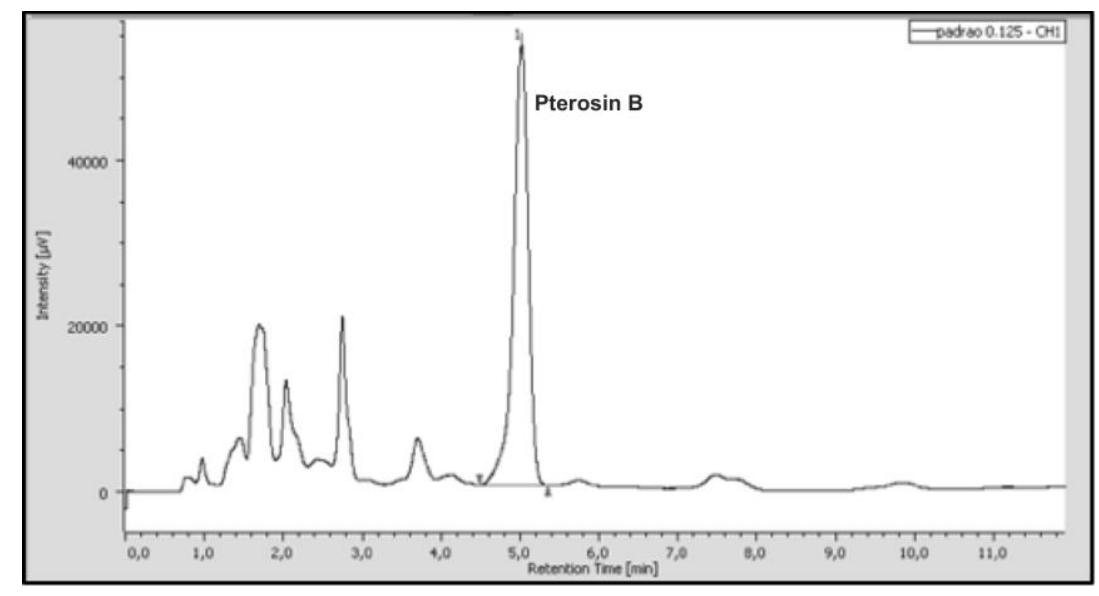

The analytical curve of the matrix fortified with $0.125 \mathrm{mmol} / \mathrm{L}, 0.5 \mathrm{mmol} / \mathrm{L}$, and $1.0 \mathrm{mmol} / \mathrm{L}$ concentrations of pterosin $\mathrm{B}$ is shown in Figure 2. The results of the regression coefficient of the analytical curves showed that the matrix had an effect on the analyte (pterosin B). The mean recovery at $1.0 \mathrm{mmol} / \mathrm{L}$ concentration of pterosin $\mathrm{B}$ was $102.0 \%$, ranging from $94.4 \%$ to $106.5 \%$ with a LOD and LOQ value of $0.04 \mathrm{mmol} / \mathrm{L}$ and 0.125 $\mathrm{mmol} / \mathrm{L}$.

Concentration of ptaquiloside in milk samples collected from farms in Brazil was carried out in duplicate using extraction method $\mathrm{C}$; however, its concentration could not be detected in the analyzed milk samples.

Consumption of bracken ferns by lactating cows can result in the secretion of ptaquiloside, a carcinogen present in bracken ferns, into milk, which could have adverse effects on the consumers of this milk. In fact, milk from cows that either under experimental set-up (ALONSO-AMELOT et al., 1998) or spontaneously (FRANCESCO et al., 2011; ROSERO NEGRETE, 2013; ARANHA et al., 2014; TOBAR et al., 2014; VIRGILIO et al., 2015) ingested bracken ferns showed the presence of ptaquiloside as determined by different 
analytical methods. However, there are no reports on the presence of ptaquiloside in milk obtained from cows raised in Brazil. Therefore, an analytical method was developed for determining ptaquiloside in dairy milk using HPLC-UV system that can be easily used by different laboratories.

Figure 2. Linearity of the curve in the matrix (milk) spiked with $0.125,0.5$, and $1.0 \mathrm{mmol} / \mathrm{L}$ concentrations of pterosin B.

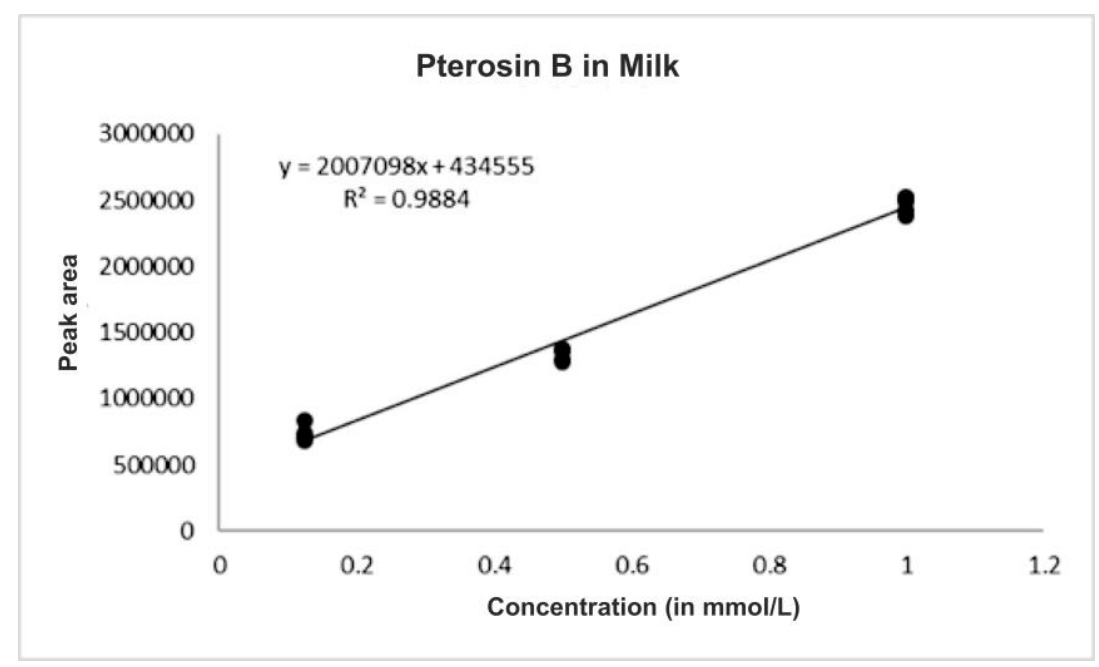

For the conversion of ptaquiloside into pterosin B followed by its extraction from milk samples, three methods were tested and compared for the recovery efficiency and quality of clean-up. Extraction method A used for the milk samples was based on the QuEChERS method modified by Oliveira et al. (2014). This methodology was efficient in the removal of fat and proteins, because acetonitrile allows the extraction of smaller quantities of lipophilic co-extractives. Another advantage of this methodology was the use of magnesium sulfate, which is an efficient salt in reducing aqueous phase of the sample and in promoting heating of the solution thereby favoring the extraction procedure. However, although efficient in cleaning, this method failed to recover pterosin $\mathrm{B}$ in the matrix fortification tests. Extraction method B was also efficient in removal of fat and proteins from the matrix, however, like extraction method $\mathrm{A}$, it failed to recover pterosin B in the matrix fortification tests.

For extraction method C, samples were treated with $\mathrm{KOH}$ to alkalinize the aqueous solution followed by heat treatment for converting ptaquiloside into pterosin B, as described previously (ALONSO-AMELOT et al., 1998; FRANCESCO et al., 2011; ROSERO NEGRETE, 2013; TOBAR et al., 2014). Subsequently, dichloromethane was used as a solvent for extraction followed by freezing and centrifugation to achieve efficient separation of fat and proteins. The dichloromethane fraction was separated and finally cleaned-up using silica gel. This extraction methodology was found to be efficient in cleaning of the samples and also in the recovery of the pterosin $\mathrm{B}$ in the fortification tests.

Thus, extraction method $\mathrm{C}$ was chosen as the suitable methodology for determining concentrations of ptaquiloside in milk. However, ptaquiloside levels could not be detected in the milk samples from farms with a history of bovine enzootic hematuria owing to the presence of $P$. arachnoideum in the grassland. A possible hypothesis is that the levels of ptaquiloside in milk samples were lower than the LOD of the analytical method in use, and therefore could not be detected. According to Alonso-Amelot et al. (1998), the amount of ptaquiloside secreted into milk was $8.6 \pm 1.16 \%$ of the total ptaquiloside 
ingested by cows for five consecutive days. Another hypothesis for the negative result in our study is that either the cows may not have consumed ferns or have been in the period when ptaquiloside was not yet secreted into milk. In fact, ptaquiloside begins to be detected in milk just after $38 \mathrm{~h}$ of ingestion of bracken fronds, and remains measurable for up to $48 \mathrm{~h}$ after its consumption (ALONSO-AMELOT et al., 1998).

In conclusion, an analytical methodology was developed using HPLC-UV for determining concentrations of ptaquiloside in dairy milk, based on its conversion to pterosin B followed by its extraction using dichloromethane. However, the concentration of ptaquiloside could not be detected in milk samples from $P$. arachnoideum infested farms in Ouro Branco city, MG, Brazil, with a history of bovine enzootic hematuria. A possible hypothesis is that the milk samples under analysis had levels of ptaquiloside lower than the LOD of the analytical method in use. Another possibility is that either the cows may not have consumed bracken fern or the milk samples were collected from cows during a period when ptaquiloside was not yet secreted into the milk.

\section{Acknowledgements}

This study received financial support from Fundação de Amparo à Pesquisa do Estado de Minas Gerais - FAPEMIG (Edital 01/2014 - Demanda Universal, process \# APQ-01394-14).

\section{References}

AGNEW, M. P.; LAUREN, D. R. Determination of ptaquiloside in bracken fern (Pteridium esculentum). Journal of Chromatography A, Amsterdam, v. 538, n. 2, p. 462-468, 1991. DOI: 10.1016/S0021-9673(01)888701

ALONSO-AMELOT, M. E.; CASTILLO, U.; SMITH, B. L.; LAUREN, D. R. Excretion, through milk, of ptaquiloside in bracken-fed cows. A quantitative assessment. Lait, Paris, v. 78, n. 4, p. 413-423, 1998. DOI: 10.1051/lait:1998440

ANJOS, B. L.; IRIGOYEN, L. F.; FIGHERA, R. A.; GOMES, A. D.; KOMMERS, G. D.; BARROS, C. S. L. Intoxicação aguda por samambaia (Pteridium aquilinum) em bovinos na Região Central do Rio Grande do Sul. Pesquisa Veterinária Brasileira, Seropédica, v. 28 , n. 10 , p. 501-507, 2008. DOI: 10.1590/S0100736X2008001000008

ARANHA, P. C. R.; HANSEN, H. C. B.; RASMUSSEN, L. H.; STROBEL, B. W.; FRIIS, C. Determination of ptaquiloside and pterosin $\mathrm{B}$ derived from bracken (Pteridium aquilinum) in cattle plasma, urine and milk. Journal of Chromatography. B, Analytical Technologies in the Biomedical and Life Sciences, Amsterdam, v. 951952,p. 44-51, 2014. DOI: 10.1016/j.jchromb.2014.01.022

FRANCESCO, B.; GIORGIO, B.; ROSARIO, N.; SAVERIO, R. F.; GIOVANNI, F. de; ROMANO, M.; ADRIANO, S.; CINZIA, R.; ANTONIO, T.; FRANCO, R.; VALERIA, R.; SANTE, R. A new, very sensitive method of assessment of ptaquiloside, the major bracken carcinogen in the milk of farm animals. Food Chemistry, Barking, v. 124, n. 2, p. 660-665, 2011. DOI: $10.1016 /$ j. foodchem.2010.05.059

FURLAN, F. H.; MENDES, E. R. S.; DUCATTI, K. R.; MARCON, G. C.; DOMBROSKY, T.; AMORIM, T. M.; RIET-CORREA, F. Intoxicação aguda por Pteridium arachnoideum e Pteridium caudatum em bovinos e distribuição das plantas em Mato Grosso. Pesquisa Veterinária Brasileira, Seropédica, v. 34, n. 4, p. 343348, 2014.

INSTITUTO NACIONAL DE METROLOGIA, NORMALIZAÇÃO E QUALIDADE INDUSTRIAL - INMETRO. Orientações sobre validação de métodos analíticos. DOQ-CGCRE-008. Rio de Janeiro: Inmetro, 2011. $20 \mathrm{p}$.

MICHELOUD, J. F.; COLQUE-CARO, L. A.; MARTINEZ, O. G.; GIMENO, E. J.; RIBEIRO, D. S. F.; SOTO-BLANCO, B. Bovine enzootic haematuria from consumption of Pteris deflexa and Pteris plumula in northwestern Argentina. Toxicon, Oxford, v. 134, p. 26-29, 2017. DOI: 10.1016/j.toxicon.2017.05.023

OLIVEIRA, F. A. S.; MADUREIRA, F. D.; LOPES, R. P.; FERREIRA, M. G.; SOTO-BLANCO, B.; MELO, M. M. Optimization of chromatographic conditions and comparison of extraction efficiencies of four different methods for determination and quantification of pesticide content in bovine milk by UFLC-MS/MS. Química Nova, São Paulo, v. 37, n. 10, p. 1699-1706, 2014. DOI: $10.5935 / 0100-4042.20140264$ 
RIBEIRO, D. S. F. Validação de método e determinação de ptaquilosídeo e pterosina B por cromatografia líquida de alta eficiência em samambaias e no leite de vacas. 2018. Tese (Doutorado em Ciência Animal) - Escola de Veterinária. Universidade Federal de Minas Gerais, Belo Horizonte.

ROSERO NEGRETE, D. M. R. Extracción, identificación, cuantificación de Ptaquilósido en leche de ganado vacuno que pastorea en zonas donde crece Pteridium arachnoideum. 2013. Tesis (Grado de Químico Farmacéutico) - Facultad de Ciencias Químicas de la Universidade Central del Ecuador, Quito.

TOBAR, A. C.; SÁNCHEZ, L. M.; MANCEBO, B.; MARRERO, E.; CHIRIBOGA, X.; SILVA, J. Residualidad del ptaquilósido en la leche procedente de granjas bovinas em tres cantones de la provincia Bolívar, Ecuador. Revista de Salud Animal, La Habana, v. 36, n. 1, p. 19-27, 2014.
VIRGILIO, A.; SINISI, A.; RUSSO, V.; GERARDO, S.; SANTORO, A.; GALEONE, A.; TAGLIALATELASCAFATI, O.; ROPERTO, F. Ptaquiloside, the major carcinogen of bracken fern, in the pooled raw milk of healthy sheep and goats: an underestimated, global concern of food safety. Journal of Agriculture and Food Chemistry, Washington, v. 63, n. 19, p. 4886-4892, 2015. DOI: 10.1021/acs.jafc.5b01937

YAMADA, K.; OJIKA, M.; KIGOSHI, H. Ptaquiloside, the major toxin of bracken, and related terpene glycosides: chemistry, biology and ecology. Natural Product Reports, London, v. 24, n. 4, p. 798-813, 2007. DOI: $10.1039 / \mathrm{B} 614160 \mathrm{~A}$

YANEZ, A.; MARQUEZ, G. J.; MORBELLI, M. A. Palynological analysis of Dennstaedtiaceae taxa from the paranaense phytogeographic province that produce trilete spores II: Microlepia speluncae and Pteridium arachnoideum. Anais da Academia Brasileira de Ciências, Rio de Janeiro, v. 88, n. 2, p. 877-890, 2016. DOI: $10.1590 / 0001-3765201620150230$ 
Semina: Ciências Agrárias, Londrina, v. 40, n. 4, p. ????-????, jul./ago. 2019 